\title{
EFFECT OF FOLIAR ZnO AND FeO NANOPARTICLES APPLICATION ON GROWTH AND NUTRITIONAL QUALITY OF RED RADISH AND ASSESSMENT OF THEIR ACCUMULATION ON HUMAN HEALTH
}

\author{
ABDEL WAHAB M. MAHMOUD ${ }^{1}$, SUZY M. ABDELAZIZ ${ }^{3}$, MOHAMED M. EL-MOGY², \\ EMAD ABDELHAMEED ABDELDAYM ${ }^{2 *}$
}

\author{
${ }^{1}$ Plant Physiology Department, Faculty of Agriculture, Cairo University, Giza, Egypt \\ ${ }^{2}$ Vegetable Crops Department, Faculty of Agriculture, Cairo University, Giza, Egypt \\ ${ }^{3}$ Department of Cross pollinated vegetable crops, Agriculture Research Centre, Giza, Egypt
}

\begin{abstract}
MAHMOUD, A.W.M. - ABDELAZIZ, S.M. - EL-MOGY, M.M. - ABDELDAYM, E.A.: Effect of foliar ZnO and $\mathrm{FeO}$ nanoparticles application on growth and nutritional quality of red radish and assessment of their accumulation on human health. Agriculture (Pol’nohospodárstvo), vol. 65, 2019, no. 1, pp. 16-29.
\end{abstract}

In order to assess the effects of green synthesized nanoparticles (GNPs) of Zn and Fe oxides on plant growth traits, photosynthetic capacity and nutritional quality of red radish (cv. Champion), two open field experiments were organised based on RCBD with four replicates. Treatments included: chicken manure, foliar application of $\mathrm{ZnO}+\mathrm{FeO}$ (GNPs at a rate of 60 and $50 \mathrm{ppm}$, respectively), chicken manure plus $\mathrm{ZnO}+\mathrm{FeO}$ (GNPs). This study revealed that growth and yield of radish plants significantly increased by $\mathrm{ZnO}+\mathrm{FeO}$ nanoparticles application. The maximum vegetative growth, leaf pigments and root quality (diameter and weight) were recorded in plants treated with $\mathrm{ZnO}+\mathrm{FeO}$ (GNPs) alone or in combination with chicken manure. Furthermore, the combined application of chicken manure with $\mathrm{ZnO}$ and $\mathrm{FeO}$ significantly improved the concentration of anthocyanins, phenols, tannins, flavonoids, crude protein and carbohydrates contents in radish root than single treatment. Similar trends were noted in photosynthesis rate, water use efficiency and values of $\mathrm{Zn}$ and Fe contents. In addition, health risk index for $\mathrm{Zn}$ and $\mathrm{Fe}$ were less than 1, which indicated to red radish plants supplied with $\mathrm{ZnO}$ and $\mathrm{FeO}$ GNPs were free of risks on human health. It was concluded that combination between chicken manure and $\mathrm{ZnO}+\mathrm{FeO} \mathrm{GNPs}$ can be considered as appropriate strategy for improving yield and nutritional status of red radish.

Key words: Raphanus sativus, health risk index, foliar application, leaf gas exchange, primary and secondary metabolites

Red radish (Raphanus sativus) is one of the most important vegetable crops belongs to Brassicaceae family. It grows well worldwide; especially in both tropical and subtropical regions. In ancient era, the radish had been grown intensively in the Mediterranean regions and subsequently its cultivation expanded in China and in Japan (Kitamura 1958). In recent decades, several researches focused on potential medical properties of radish. Where, the red radish has significant amounts of minerals, vitamin $\mathrm{C}$ and by-products which play key role in human health. Numerous studies con- firmed that plant phenols have many medical benefits and used as anti-inflammatory, anti-allergic (Rashid \& Ryan 2004; Duartea et al. 2018) anti-atherosclerotic, anti-thrombotic, antiviral (Catel-Ferreira et al. 2015), anti-bacterial (Cushnie \& Lamb 2011), and anti-carcinogenic agents (Ibrahim et al. 2012). Furthermore, the red colour in radish genotypes is associated to anthocyanins and its derivatives. Pelargonidin, one of anthocyanins derivatives in red radish, is stable natural colorant for enhancing the foodstuff colour (MüllerMaatsch et al. 2016). 
Many scientists reported that micronutrients had simulative influence on plant biomass, yield quantity and accumulation of by-products compounds in economic parts of plants (Welch \& Shuman 1995). On the other wise, unavailability of micronutrients, especially zinc and iron, in Mediterranean soils is significantly correlated to some soil chemical properties such as high $\mathrm{pH}$, high salinity level, and low organic matter as well as have free calcium carbonate. Consequently, micronutrient deficiencies in those soils are considered the most important limiting factor to crop quantity and quality (Prasad et al. 2012). Shortages of iron (Fe) and zinc ( $\mathrm{Zn})$ in food are a worldwide problem, impairing growth of children and development of pregnant and lactating women (Stein 2010). Micronutrient bio-fortification, the technique of elevating micronutrients containing $\mathrm{Fe}$ and $\mathrm{Zn}$ in the edible parts of economic crops, considered as sustainable and applicable approach to reduce micronutrient malnutrition (Bevis 2015).

In addition, policy of various governments worldwide, including the European Union (EC 2007) had deeply prohibited the overuse of agrochemical inputs, pushing to assume alternative and sustainable strategies. The one of most innovative and sustainable strategy to overcome the problem of micronutrient deficiency in alkaline soil is convert their salts into nano-forms and spraying them as foliar fertilisers on plants or coating the nano-fertilisers with nano-materials to control released nutrients (Rashid \& Ryan 2004). In particular, nanomaterial recently has been used widely in various scientific areas as medicinal, pharmaceutical, physical and agricultural science (Duhan et al. 2017). These materials have been employed in several agriculture practices due to their efficiency in plant protection and nutrition (Iavicoli et al. 2017). Green synthesized nanofertilisers can be defined as synthesize nanonutrients from plant and/or microorganisms materials, this is better than using chemical materials that leave hazard compounds in the environment (Thakur et al. 2018). Utilization of foliar, capsulated or green synthesized nanofertilisers is a new strategy has started to attract attention in agriculture currently. They are also considered the most important promising approaches for sustainable agriculture with high production, low deterioration and feed the world grown rapidly (Sekhon 2014). Substitution of green synthesized nanofertiliser with traditional fertilisers is approach to reduce nutrient losses, improve soil fertility, conserve energy and increase farm profitability (Naderi \& Abedi 2012; Mishra et al. 2016). In agriculture area, nanotechnology can provide friendly environmentally strategy to remediate water and soils, thus promoting world food production and quality (Prasad et al. 2014; Sekhon 2014). In this regard, foliar application of nanoformulation micronutrient also is considered more proper than the land application, due to the quickly overcoming on deficient, easy to apply, minimizing of the toxicity resulting of accumulation micronutrient and avoiding the immobilization of trace elements in soil. Zinc and iron elements are playing fundamental role in building or activation of various enzymes involves to nutrients absorption, biosynthesis of metabolic compounds and phytohormone formation (Dhir et al. 2011; Elanchezhian et al. 2017). Zinc and iron deficiency in plants can cause distinctive symptoms; included leaf necrosis, stunted growth, reduced leaf size and number, reduced crop quality and quantity (Fageria 2016). These symptoms are more associated to some physiological processes as rate of transpiration and photosynthesis, dysfunction of relevant enzymes, reduced of nutrient absorption, plant wilting and imbalance water relations (Prasad 2004; Dhir et al. 2011).

This investigation is aim to examine the combined application of $\mathrm{ZnO}$ and $\mathrm{FeO}$ GNPs on plant growth and foodstuff content of red radish, with considering impact of this practice on human health. The difference in mean plant biomass, indigenous nutrient content, pigments concentration, secondary compounds and photosynthetic parameters of red radish among treatments were also evaluated.

\section{MATERIAL AND METHODS}

\section{Experimental design and location}

This study was performed at Giza Governorate, Egypt over two winter seasons (first of October until the middle of December 2016 and 2017). This area is located in $30^{\circ} 01^{\prime} 10.3$ ' $\mathrm{N}, 31^{\circ} 10^{\prime} 05.9^{\prime \prime} \mathrm{E}, 24 \mathrm{~m}$ above sea level. Physical-chemical analysis of experimental soil and applied chicken manure are 
shows in Tables 1, 2. Prior to sowing, the soil of experiments were mechanically ploughed and planked twice till the soil surface has been settled and established the plots. The seeds $(15 \mathrm{~g})$ of red radish $(R a-$ phanus sativus cv. Champion) were sown in each plots with a distance of $40 \mathrm{~cm}$ between rows and $5 \mathrm{~cm}$ between plants in plots with $6 \mathrm{~m}^{2}(3 \mathrm{~m} \times 2 \mathrm{~m})$. The treatments included: 1) soil application of chicken manure at the rate of $9.6 \mathrm{t} / \mathrm{ha}, 2)$ foliar application with GNPs of $\mathrm{FeO}(50 \mathrm{ppm})$ and $\mathrm{ZnO}$ (60 ppm) and 3) soil application of chicken manure $(9.6 \mathrm{t} / \mathrm{ha})$ plus foliar supplementation of $\mathrm{FeO}$ (50 ppm) and $\mathrm{ZnO}(60 \mathrm{ppm})$. The treatments were arranged in randomized complete block design with four replicates. The plants of radish were supplied with $\mathrm{ZnO}+\mathrm{FeO}$ GNPs after 30 days from sowing for two times with 15 days interval as recommended by Elizabath et al. (2017). All treatments were received the recommended doses of mineral fertilisers $\left(50 \mathrm{~kg} \mathrm{~N}, 25 \mathrm{~kg} \mathrm{P}_{2} \mathrm{O}_{5}\right.$, and $\left.125 \mathrm{~kg} \mathrm{~K} / \mathrm{ha}\right)$. After 70 day, all roots samples were collected from each treatment for chemical analysis.

\section{Green synthesis of zinc oxide and iron oxide NPs}

Nano iron was extracted from Saccharomyces cerevisiae cells in suspension culture, which obtain from Microbiology Department of National Research Centre, Giza, Egypt, as described by Bağ et al. (1998). All cultures were centrifuged, washed repeatedly and dialyzed until no free iron ion was observed in the deionized water. Then, precipitation in aqueous ammonia $(0.3 \mathrm{~mol} / \mathrm{L})$ and coated tetramethylammonium hydroxide under vigorous stirring for $2 \mathrm{~h}$ using magnetic stirring, precipitate was then separated by magnetic filtration using a permanent magnet, and washed with distilled water until a neutral $\mathrm{pH}$ was obtained. Nano zinc extracted from lactic acid bacteria (LAB) (Leuconostoc mesenteroides) according to Mrvcic et al. (2009). This strain was developed by Microbiology Department, Faculty of Agriculture, Cairo University, Egypt. Transmission electron microscope (TEM) was performed to determine the nano size of the used elements (Figure 1A, B).

\section{Plant growth parameters and total yield}

Ten plants from each plot were selected randomly to estimate growth parameters of radish plants. Chlorophyll concentration and leaf area were measured on adult fourth leaf of each plant using Chlorophyll meter (model SPAD 502 Minolta Co. Japan) and leaf area meter (model C1 202 Laser Areame-
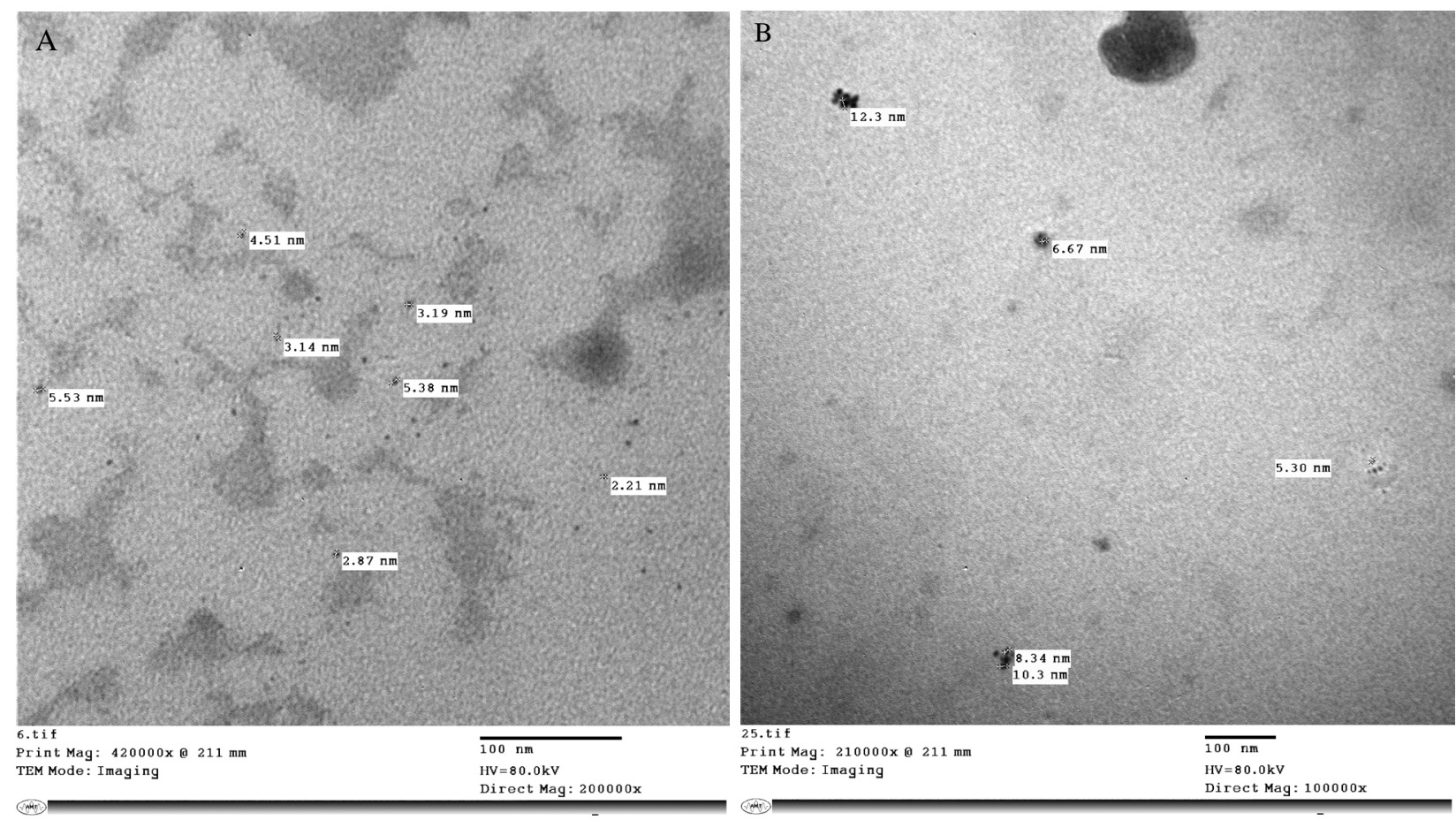

Figure 1. (A) Scanning Electron Microscopy (SEM) for green synthesized of FeO NPs and (B) For ZnO NPs 
ter), respectively. Plant height was determined using a graduated meter and root diameters using digital calliper. Fresh weight of roots was measured using a digital balance. Root dry weight was recorded using forced-air drying oven at $75^{\circ} \mathrm{C}$ until constant the weight. The weight of radish roots per experimental plot was recorded and total yield was calculated in ton per hectare.

Total phenolic compounds, tannins content, and total flavonoids in roots

Total phenolic compounds were measured by spectrophotometric method and using Folin-Ciocalteu reagent according to Singleton \& Rossi (1965). Concentration of tannins in root were quantified by using Folin-Ciocalteu reagent method and the results were expressed as milligrams gallic acid equivalent per gram of dry weight (mg GAE/g dry weight) as described by Chahardehi et al. (2009). Total flavonoid was determined by using Meda et al. (2005) method with minor modifications. Briefly, $0.25 \mathrm{~mL}$ of sample $(1 \mathrm{mg} / \mathrm{mL})$ was added to a tube containing $1 \mathrm{~mL}$ of double-distilled water. Next, $0.075 \mathrm{~mL}$ of $5 \% \mathrm{NaNO}_{2}, 0.075 \mathrm{~mL}$ of $10 \% \mathrm{AlCl}_{3}$ and $0.5 \mathrm{~mL}$ of $1 \mathrm{M} \mathrm{NaOH}$ were added at 0,5 and $6 \mathrm{~min}$, sequentially. Finally, the volume of the reacting solution was adjusted to $2.5 \mathrm{~mL}$ with double-distilled water. The absorbance of the solution at a wavelength of $410 \mathrm{~nm}$ was detected using the Ultrospec 2100 pro spectrophotometers. Quercetin is a ubiquitous flavonoid, present in many plant extract, was used as standard to quantify the total flavonoid content of hot water extract of the spice extracts.

Crude protein, total carotenoids, total carbohydrates, and total anthocyanins in roots

The total nitrogen content $(\mathrm{N})$ was determined by using the modified-micro-Kjeldahel method as described by AOAC (1990). Protein content was estimated through multiplying values of nitrogen in conversion factor (6.25). Total carotenoids were calculated as described by Nornai (1982) method. Determination of total carbohydrates were performed using phosphomolybdic acid method as described by Helrich (1990). Total anthocyanins were extracted from fresh radish root with ethanol and $\mathrm{HCl}(85: 15)$ at $5^{\circ} \mathrm{C}$ overnight. The extract solution was measured at wavelength $520 \mathrm{~nm}$. The concentration of anthocyanins was calculated as described by Francis (1982).
Photosynthesis rate, respiration rate, and water use efficiency

Measurement of photosynthesis rate on an area basis $\left(\mu \mathrm{mol} \mathrm{CO}_{2} / \mathrm{m}^{2} / \mathrm{s}\right.$ ), respiration rate $\left(\mathrm{mol} \mathrm{H} / 2 \mathrm{O} / \mathrm{m}^{2} / \mathrm{s}\right)$, and water use efficiency of five different leaves per treatment was monitored using a LICOR 6400 (Lincoln, Nebraska, USA) infrared gas analyzer (IRGA). Light intensity (Photosynthetically active radiation, PAR) within the sampling chamber was set at $1,500 \mu \mathrm{mol} / \mathrm{m}^{2} / \mathrm{s}$, using a Li-6400-02B LED light source (LICOR). The $\mathrm{CO}_{2}$ flow into the chamber was maintained at a concentration of $400 \mu \mathrm{mol} / \mathrm{mol}$ using an LI-6400-01 $\mathrm{CO}_{2}$ mixer (LI-COR). The measurements were performed at mooring between 9:00 and 12:00 a.m. Water use efficiency (WUE) of radish leaf was calculated as the ratio between net $\mathrm{CO}_{2}$ exchange and transpiration from measurements of leaf gas exchange (Erice et al. 2011).

\section{Determination of $\mathrm{Zn}$ and $\mathrm{Fe}$ concentrations in roots}

Dried samples $(0.5 \mathrm{~g})$ were digested by concentrated $\mathrm{H}_{2} \mathrm{SO}_{4}(99.7 \%)$. Concentration of $\mathrm{Fe}$ and $\mathrm{Zn}$ were determined using atomic absorption spectrophotometer (Pye Unicam model SP-1900, US) according to method described by Allen et al. (1984).

\section{Intake risk assessment}

Intake risk of $\mathrm{Fe}$ and $\mathrm{Zn}$ supplied to red radish due to the application of green nanoparticles of $\mathrm{ZnO}$ and $\mathrm{FeO}$ on human health was considered by different methods. These methods include the daily intake of metals (DIM) along with the methods used for the health risk assessment (Alloway 1995; Hodson 2004). The health risk assessment methods include hazard quotient (HQ) and health risk index (HRI) (Rattan et al. 2005; Khan et al. 2015). Intake risk assessment was calculated using the equations below:

$$
\begin{gathered}
\text { Hazard quotient }(\mathrm{HQ})=\left(\mathrm{W}_{\text {plant }}\right) \\
\times\left(\mathrm{M}_{\text {plant }}\right) /\left(\mathrm{R}_{\mathrm{f}} \mathrm{D} \times \mathrm{B}\right)
\end{gathered}
$$

where: $\mathrm{W}_{\text {plant }}$ - the dry weight of contaminated plant materials [mg/d], $M_{\text {plant }}$ - the concentration of metal in vegetables $[\mathrm{mg} / \mathrm{kg}], \mathrm{R}_{\mathrm{f}} \mathrm{D}$ - the food reference 
dose for the metal [values of $\mathrm{Zn}$ and $\mathrm{Fe}$ are 0.30 and $0.70 \mathrm{mg} / \mathrm{kg}$ bw/day, respectively] and B is the body mass [65 kg] according to WHO (1993)

$$
\begin{gathered}
\text { DIM (Daily Intake of Metals })=\mathrm{C}_{\text {metal }} \times \mathrm{C}_{\text {factor }} \\
\times\left(\mathrm{D}_{\text {food intake }} / \mathrm{B}\right)
\end{gathered}
$$

where: $\mathrm{C}_{\text {metal }}$ is the heavy metals concentration in plant $[\mathrm{mg} / \mathrm{kg}] ; \mathrm{C}_{\text {factor }}-$ the conversion factor (0.085), $\mathrm{D}_{\text {food intake }}$ - the value of the daily intake of vegetable

$$
\text { HRI (Health Risk Index) }=\mathrm{DIM} / \mathrm{R}_{\mathrm{f}} \mathrm{D} \text {. }
$$

\section{Data analysis}

The interactions between treatments and years for the all variables studied were insignificant; so data were combined over the two growing seasons. The treatments were arranged in randomized complete block design with four replicates. The obtained data from combined analysis were subjected to the statisticall analysis of variance and means were compared at 0.05 level according to Tukey test using SPSS software version 13. Correlation analysis was performed using Pearson correlation methods.

\section{RESULTS}

Chemical analysis of soil and applied chicken manure

Experimental soil is characterized by clay texture according to USDA soil textural classification system (USDA 1998), alkaline $\mathrm{pH}$, with low value of available $\mathrm{Zn}$ and Fe contents. The electrical conductivity (EC) of the soil was $1.65 \mathrm{dS} / \mathrm{m}$ which classified as non-saline soil. Organic matter and total $\mathrm{N}$ contents in the soil analysis indicated a medium level of fertility (Table 1). Available phosphorus (P) content resulted low probably because the high calcium content that is responsible for the removal of $\mathrm{P}$ as insoluble calcium phosphates salts (Abdel-Dayem et al. 2012).

Table 2 refers to chemical properties of used chicken manure during two seasons. Chicken manure was characterized by a natural $\mathrm{pH}$, a high organic matter $(\mathrm{OM})$ content but a low $\mathrm{C} / \mathrm{N}$ ratio (18.20 and 14.70 in the first and the second year, respectively. The difference in $\mathrm{C} / \mathrm{N}$ ratio could be attributed to amount carbon-rich material (sawdust)

$\mathrm{T}$ a

Physical-chemical properties of experimental soil during the two seasons

\begin{tabular}{|l|c|c|}
\hline Parameter & 2016 & 2017 \\
\hline Texture & Clay & Clay \\
Clay [\%] & 37.10 & 37.80 \\
Silt [\%] & 36.20 & 35.90 \\
Fine sand [\%] & 22.90 & 23.10 \\
pH & 7.76 & 7.87 \\
EC [dS/m] & 1.65 & 1.59 \\
Organic matter [\%] & 1.55 & 1.77 \\
Ca $^{++}[\mathrm{meq} / 1]$ & 7.10 & 7.24 \\
Mg $^{++}[\mathrm{meq} / 1]$ & 2.87 & 3.01 \\
$\mathrm{~K}^{+}[\mathrm{meq} / \mathrm{l}]$ & 0.27 & 0.33 \\
Na ${ }^{+}[\mathrm{meq} / \mathrm{l}]$ & 5.88 & 6.22 \\
Available Zn [ppm] & 0.29 & 0.33 \\
Available Fe [ppm] & 2.87 & 3.26 \\
Available N [ppm] & 27.10 & 30.10 \\
Available P [ppm] & 20.54 & 22.55 \\
\hline
\end{tabular}


T a b 1 e 2

Chemical analysis of applied chicken manure over two seasons

\begin{tabular}{|l|c|c|}
\hline Parameter & 2016 & 2017 \\
\hline Total N [\%] & 2.60 & 3.02 \\
Total P [\%] & 0.70 & 0.97 \\
Total K [\%] & 1.15 & 1.21 \\
Total Fe [ppm] & 26.50 & 30.20 \\
Total Zn [ppm] & 34.30 & 32.10 \\
Total Mn [ppm] & 16.00 & 15.70 \\
pH & 6.87 & 6.80 \\
C/N ratio & 18.20 & 12.70 \\
Organic matter [\%] & 62.40 & 66.50 \\
\hline
\end{tabular}

$\mathrm{T}$ a $\mathrm{b} 1 \mathrm{e} \quad 3$

Effect of treatments on plant growth parameters, chlorophyll of leaves, and total yield of red radish

\begin{tabular}{|l|c|c|c|}
\hline Growth parameters & $\begin{array}{c}\text { Chicken manure } \\
(\mathrm{T} 1)\end{array}$ & $\begin{array}{c}\text { FeO }+\mathrm{ZnO} \text { GNPs } \\
(\mathrm{T} 2)\end{array}$ & $\begin{array}{c}\text { Chicken manure }+\mathrm{FeO}+\mathrm{ZnO} \\
(\mathrm{T} 3)\end{array}$ \\
\hline Plant height [cm] & $24.35 \pm 1.85^{\mathrm{b}}$ & $23.50 \pm 1.40^{\mathrm{b}}$ & $26.01 \pm 0.67^{\mathrm{a}}$ \\
Leaf area $\left[\mathrm{cm}^{2}\right]$ & $73.61 \pm 1.30^{\mathrm{b}}$ & $72.86 \pm 1.55^{\mathrm{b}}$ & $77.49 \pm 1.66^{\mathrm{a}}$ \\
Fresh weight of root [g] & $59.71 \pm 1.51^{\mathrm{b}}$ & $61.53 \pm 1.09^{\mathrm{ab}}$ & $63.33 \pm 0.46^{\mathrm{a}}$ \\
Dry weight of root [g] & $11.88 \pm 0.47^{\mathrm{c}}$ & $12.68 \pm 0.06^{\mathrm{bc}}$ & $14.98 \pm 0.13^{\mathrm{a}}$ \\
Root diameter [mm] & $20.31 \pm 0.30^{\mathrm{b}}$ & $18.01 \pm 0.40^{\mathrm{c}}$ & $23.07 \pm 0.62^{\mathrm{a}}$ \\
Leaf chlorophyll [SPAD] & $35.35 \pm 0.70^{\mathrm{c}}$ & $37.84 \pm 0.44^{\mathrm{b}}$ & $40.76 \pm 0.65^{\mathrm{a}}$ \\
Leaf carotenoids [mg/g fw] & $7.45 \pm 0.37^{\mathrm{b}}$ & $7.23 \pm 0.46^{\mathrm{b}}$ & $8.58 \pm 0.46^{\mathrm{a}}$ \\
Total yield [t/ha] & $16.06 \pm 1.49^{\mathrm{b}}$ & $16.87 \pm 1.22^{\mathrm{ab}}$ & $18.48 \pm 0.30^{\mathrm{a}}$ \\
\hline
\end{tabular}

Values \pm SD followed by the same letter are not statistically different according to Tukey test $(P<0.05 \%)$

$\mathrm{T}$ a

Effect of treatments on primary and secondary metabolic compounds of radish root over two seasons

\begin{tabular}{|l|c|c|c|}
\hline Chemical composition & $\begin{array}{c}\text { Chicken manure } \\
(\mathrm{T} 1)\end{array}$ & $\begin{array}{c}\text { FeO }+\mathrm{ZnO} \text { GNPs } \\
(\mathrm{T} 2)\end{array}$ & $\begin{array}{c}\text { Chicken manure }+\mathrm{FeO}+\mathrm{ZnO} \\
(\mathrm{T} 3)\end{array}$ \\
\hline Total phenols [\%] & $62.74 \pm 0.56^{\mathrm{c}}$ & $67.05 \pm 0.81^{\mathrm{b}}$ & $74.81 \pm 0.70^{\mathrm{a}}$ \\
Tannins [mg GAE/g dw] & $51.02 \pm 1.49^{\mathrm{b}}$ & $53.59 \pm 1.62^{\mathrm{ab}}$ & $55.17 \pm 1.30^{\mathrm{a}}$ \\
Total flavonoids [\%] & $22.69 \pm 1.10^{\mathrm{b}}$ & $24.99 \pm 1.11^{\mathrm{ab}}$ & $27.07 \pm 0.92^{\mathrm{a}}$ \\
Crude protein [\%] & $4.87 \pm 0.56^{\mathrm{b}}$ & $4.72 \pm 0.22^{\mathrm{b}}$ & $5.88 \pm 0.56^{\mathrm{a}}$ \\
Total carbohydrates [\%] & $20.57 \pm 1.57^{\mathrm{c}}$ & $23.85 \pm 1.08^{\mathrm{b}}$ & $25.99 \pm 1.04^{\mathrm{a}}$ \\
Anthocyanins [mg/100 g fw] & $152.81 \pm 6.19^{\mathrm{c}}$ & $156.02 \pm 4.51^{\mathrm{b}}$ & $164.63 \pm 5.14^{\mathrm{a}}$ \\
\hline
\end{tabular}

Values \pm SD within each line followed by the same letter are not statistically different according to Tukey test $(P<0.05 \%)$ 

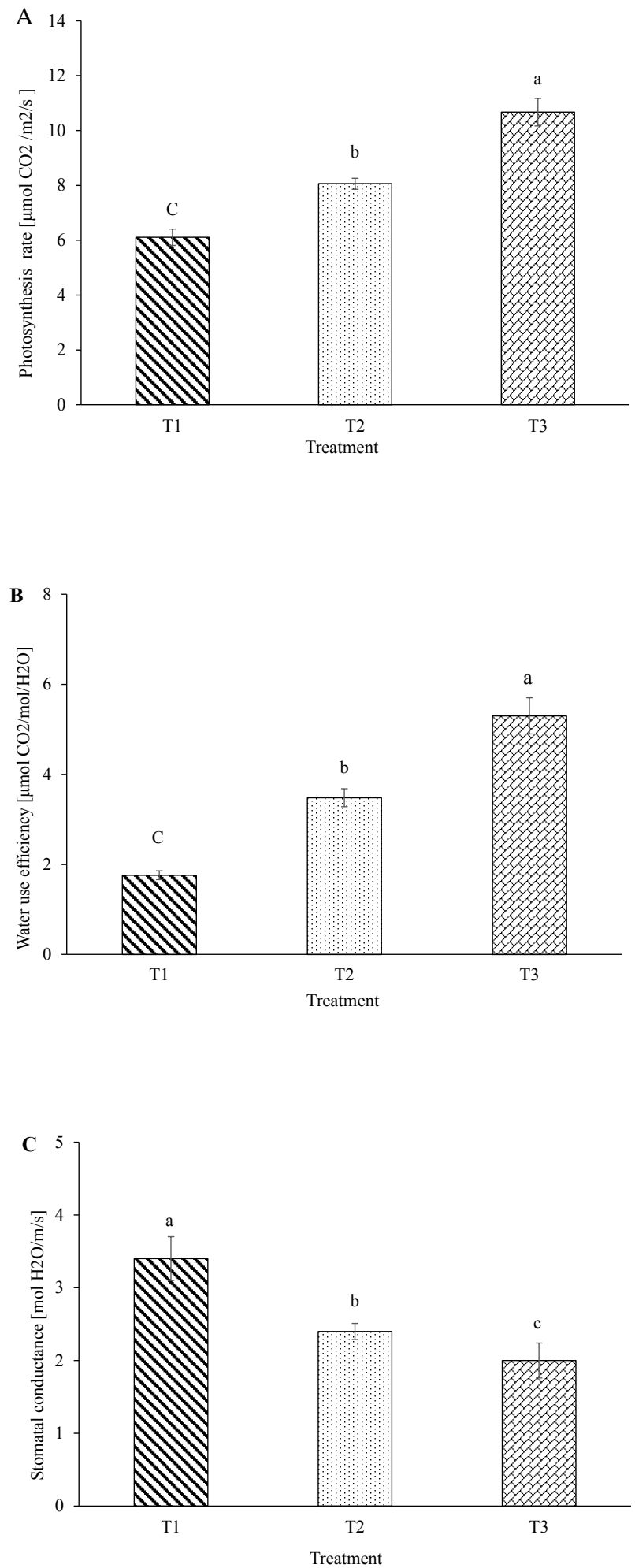

Figure 2. Effect of treatments $(\mathrm{T} 1=$ Plants amended with chicken manure alone, $\mathrm{T} 2=$ Plants supplied with foliar $\mathrm{FeO}$ $+\mathrm{ZnO}$ GNPs, and T3 = Plants amended with chicken manure and $\mathrm{FeO}+\mathrm{ZnO}$ GNPs) on (A) photosynthesis rate, (B) water use efficiency, (C) transpiration rate. Columns followed by the same letter are not statistically different according to Tukey test $(P<0.05 \%)$. Vertical bars indicate to standard deviation $( \pm \mathrm{SD})$. that mixed with chicken dungs, where it was low in second year (2017). Similar results were observed by Troy et al. (2012) who found that the $\mathrm{C} / \mathrm{N}$ ratio of pig manure increased with increasing the amount of sawdust used. This manure also has proper amount of total N, P, Ca, K, Zn and Fe that probably were rapidly mineralized in soil considering the low $\mathrm{C} / \mathrm{N}$ ratio, especially, in second season $(\mathrm{C} / \mathrm{N}=14.6)$.

\section{Plant growth and total yield}

Data in Table 3 shows that foliar application of $\mathrm{ZnO}$ and $\mathrm{FeO}$ GNPs positively improved vegetative growth and total yield of red radish grown in clay soil. The statistical analysis showed that the highest values of plant height, leaf area, fresh and dry weight of root, root diameter, total chlorophyll, and total yield were recorded in T3 treatment. Moreover, insignificant differences were noted among $\mathrm{T} 1$ treatment and T3 in pervious parameters, except root diameter and total chlorophyll content. The highest value of total chlorophyll content was found in T3 $(40.76 \pm 0.65)$ while, T1 treatment was recorded the lowest values $(35.35 \pm 0.70)$.

Total phenolic compounds, tannins and flavonoids

The obtained results showed that concentration of total phenolic compounds; tannins and flavonoids in roots of red radish were also affected by foliar application of $\mathrm{ZnO}$ and $\mathrm{FeO}$ GNPs $(p<0.05$; Table $4)$. The maximum percentage $\left(74.81 \pm 0.70^{\mathrm{a}}\right)$ of total phenol in root was recorded in $\mathrm{T} 3$ followed by $\mathrm{T} 2(67.05 \pm 0.81)$ in comparison to $\mathrm{T} 1(62.74 \pm 0.56)$. Highest values of tannins and flavonoids contents in root were found in T3 compared to other treatments. Concentration of tannins and flavonoids in root increased by $10.6 \%$ and $11.9 \%$, respectively with $\mathrm{T} 3$, if compared to T1. While, the concentration of tannins and total flavonoids in radish roots remained unchanged with T1 and T2 treatments (Table 4).

Crude protein, total carbohydrates, and anthocyanins concentration

It is evident from Table 4 that concentration of crude protein, total carbohydrates, and anthocyanins in radish root over two seasons were significantly changed by application of $\mathrm{ZnO}$ and $\mathrm{FeO}$ GNPs. The highest percentage of roots crude protein content was recorded in T3 $(5.88 \pm 0.56)$ in comparison to $\mathrm{T} 1(4.87 \pm 0.56)$. While, the differences between 
$\mathrm{T} 1$ and $\mathrm{T} 2$ in roots crude protein content concentration was not significant. Such findings were found in total carbohydrate and anthocyanins concentrations. Where, the maximum percentages of carbohydrate and anthocyanins in roots were reported in T3 $(25.99 \pm 1.04$ and $164.63 \pm 5.14$, respectively) and the lowest percentage were found in $\mathrm{T} 1(20.57 \pm 1.57$ and $152.81 \pm 6.19$, respectively).

Photosynthesis rate, transpiration rate and water use efficiency

According to ANOVA analysis (Figure 2), photosynthesis rates, transpiration rate, and water use efficiency significantly affected by foliar application of $\mathrm{ZnO}$ and FeO GNPs $(p \leq 0.05)$. The combined application (T3) gave the highest values of net photosynthesis rate (Figure 2A) and water use efficiency (Figure 2B) followed by $\mathrm{T} 2$ when compared to $\mathrm{T} 1$ treatment. Conversely, lowest value of respiration rate in plant leaves was observed in $\mathrm{T} 3$ whereas the maximum value was noted in T1 (Figure 2C).

Zinc and iron concentrations in leaves and roots

As expected, the maximum concentrations of $\mathrm{Fe}$ and $\mathrm{Zn}$ in roots and leaves tissue were observed in T2 and T3 compared to T1 (Figure 3), with insignificant differences among both treatments. Higher accumulation of $\mathrm{Zn}$ and $\mathrm{Fe}$ was observed in radish root in $\mathrm{T} 3$ followed by $\mathrm{T} 2$ when compared to $\mathrm{T} 1$.

\section{Correlation study}

Data in Table 5 revealed a positive relationship between photosynthesis rate and water use efficiency with $\mathrm{Zn}$ and $\mathrm{Fe}$ accumulation in leaves and roots of treatment (T3), while a negative correlation was noted for transpiration rate. Leaf pigments, either chlorophyll or carotenoids, were correlated positively to leaf photosynthesis rate, $\mathrm{Zn}$ and $\mathrm{Fe}$ in roots

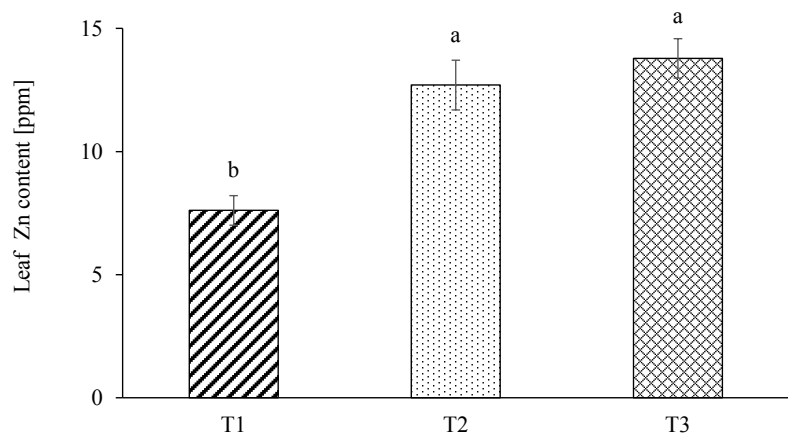

Treatment

C

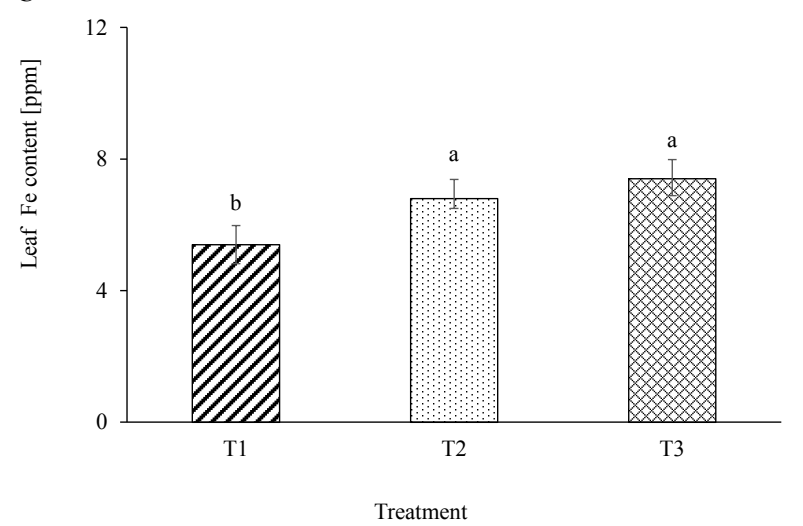

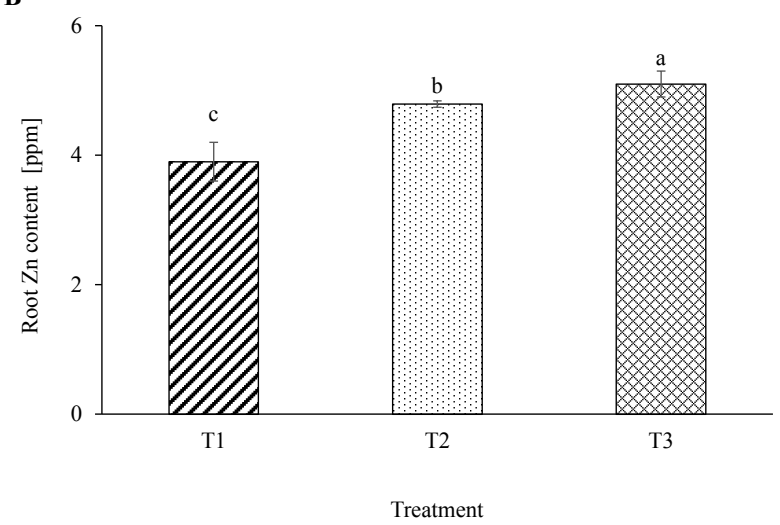

D

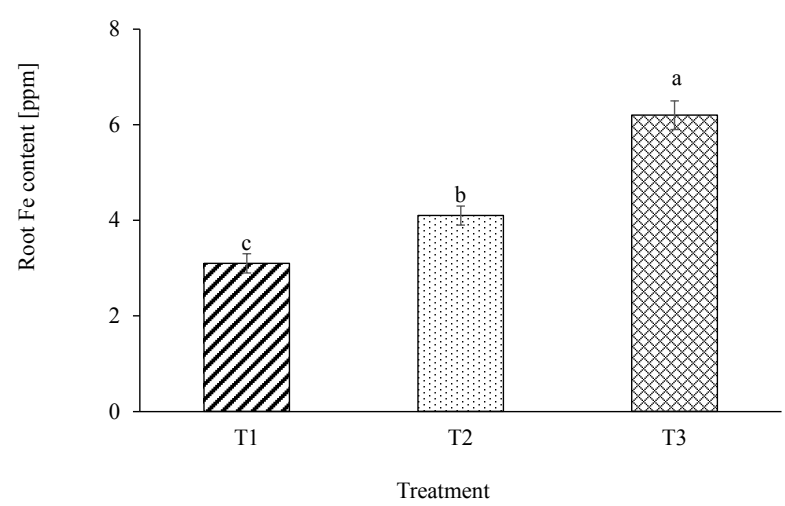

Figure 3. Effect of treatments $(\mathrm{T} 1=$ plants amended with poultry manure alone, $\mathrm{T} 2$ = plants supplied with foliar FeO $+\mathrm{ZnO}$ GNPs alone, T3 = plants amended with poultry manure and FeO + ZnO GNPs) on (A) leaf Zn content, (B) root Zn content, (C) leaf Fe content, and root $\mathrm{Fe}$ content of red radish. Columns followed by the same letter are not statistically different according to Tukey test $(P<0.05 \%)$. Vertical bar indicates to standard deviation $( \pm \mathrm{SD})$. 
T a b 1 e 5

Correlation study between $\mathrm{Zn}$ and $\mathrm{Fe}$ with tested parameters of red radish plants

\begin{tabular}{|c|c|c|c|c|c|c|c|c|c|c|}
\hline Parameters & 1 & 2 & 3 & 4 & 5 & 6 & 7 & 8 & 9 & 10 \\
\hline 1. Plant height & 1.00 & & & & & & & & & \\
\hline 2. Leaf area & $0.94^{+}$ & 1.00 & & & & & & & & \\
\hline 3. Root fresh weight & $0.84^{+}$ & $0.95^{+}$ & 1.00 & & & & & & & \\
\hline 4. Root dry weight & $0.78^{+}$ & $0.88^{+}$ & $0.95^{+}$ & 1.00 & & & & & & \\
\hline 5. Root diameter & $0.64^{+}$ & $0.72^{+}$ & $0.89^{+}$ & $0.90^{+}$ & 1.00 & & & & & \\
\hline 6. Total yield & $0.83^{+}$ & $0.69^{+}$ & $0.69^{+}$ & $0.70^{+}$ & $0.72^{+}$ & 1.00 & & & & \\
\hline 7. Root crude protein & $0.96^{+}$ & $0.95^{+}$ & $0.82^{+}$ & $0.80^{+}$ & 0.56 & $0.67^{+}$ & 1.00 & & & \\
\hline 8. Root Fe content & $0.75^{+}$ & $0.92^{+}$ & $0.88^{+}$ & $0.83^{+}$ & $0.62^{+}$ & 0.36 & $0.85^{+}$ & 1.00 & & \\
\hline 9. Leaf chlorophyll & $0.60^{+}$ & $0.79^{+}$ & $0.93^{+}$ & $0.86^{+}$ & $0.89^{+}$ & 0.50 & 0.57 & $0.79^{+}$ & 1.00 & \\
\hline 10. Leaf carotenoid content & $0.84^{+}$ & $0.83^{+}$ & $0.86^{+}$ & $0.90^{+}$ & $0.83^{+}$ & $0.92^{+}$ & $0.77^{+}$ & $0.61^{+}$ & $0.72^{+}$ & 1.00 \\
\hline 11. Root carbohydrates & $0.95^{+}$ & $0.96^{+}$ & $0.86^{+}$ & $0.83^{+}$ & $0.62^{+}$ & $0.77^{+}$ & $0.95^{+}$ & $0.81^{+}$ & $0.66^{+}$ & $0.88^{+}$ \\
\hline 12. Root phenols content & $0.95^{+}$ & $0.87^{+}$ & $0.82^{+}$ & $0.83^{+}$ & $0.74^{+}$ & $0.94^{+}$ & $0.88^{+}$ & $0.63^{+}$ & $0.59^{+}$ & $0.94^{+}$ \\
\hline 13. Root tannins & $0.83^{+}$ & $0.89^{+}$ & $0.86^{+}$ & $0.85^{+}$ & $0.68^{+}$ & $0.77^{+}$ & $0.82^{+}$ & $0.73^{+}$ & $0.74^{+}$ & $0.93^{+}$ \\
\hline 14. Root flavonoids & $0.66^{+}$ & $0.79^{+}$ & $0.92^{+}$ & $0.98^{+}$ & $0.95^{+}$ & $0.67^{+}$ & $0.65^{+}$ & $0.73^{+}$ & $0.90^{+}$ & $0.87^{+}$ \\
\hline 15. Root anthocyanins & -0.01 & -0.09 & 0.03 & 0.07 & 0.27 & 0.23 & -0.13 & -0.19 & 0.06 & 0.14 \\
\hline 16. Leaf Fe content & $0.60^{+}$ & $0.77^{+}$ & $0.91^{+}$ & $0.82^{+}$ & $0.85^{+}$ & 0.39 & 0.58 & $0.84^{+}$ & $0.96^{+}$ & 0.59 \\
\hline 17. Leaf $\mathrm{Zn}$ content & $0.61^{+}$ & $0.79^{+}$ & $0.89^{+}$ & $0.76^{+}$ & $0.79^{+}$ & 0.38 & $0.60^{+}$ & $0.84^{+}$ & $0.93^{+}$ & 0.55 \\
\hline 18. Photosynthetic rate & $0.73^{+}$ & $0.78^{+}$ & $0.91^{+}$ & 0.86 & $0.97^{+}$ & $0.75^{+}$ & $0.62^{+}$ & $0.65^{+}$ & $0.88^{+}$ & $0.81^{+}$ \\
\hline 19. Transpiration rate & 0.56 & $-0.72^{+}$ & $-0.84^{+}$ & $-0.73^{+}$ & $-0.79^{+}$ & -0.38 & $-0.54^{+}$ & $-0.76^{+}$ & $-0.88^{+}$ & -0.53 \\
\hline 20. Water use efficiency & $0.69^{+}$ & $0.77^{+}$ & $0.91^{+}$ & $0.86^{+}$ & $0.97^{+}$ & $0.70^{+}$ & 0.60 & $0.67^{+}$ & $0.90^{+}$ & $0.78^{+}$ \\
\hline 21. Root $\mathrm{Zn}$ content & $0.68^{+}$ & $0.87^{+}$ & $0.92^{+}$ & $0.91^{+}$ & $0.76^{+}$ & 0.39 & $0.77^{+}$ & $0.96^{+}$ & $0.88^{+}$ & $0.66^{+}$ \\
\hline
\end{tabular}

Table 5 continued

\begin{tabular}{|c|c|c|c|c|c|c|c|c|c|c|c|}
\hline Parameters & 11 & 12 & 13 & 14 & 15 & 16 & 17 & 18 & 19 & 20 & 21 \\
\hline 1. Plant height & & & & & & & & & & & \\
\hline 2. Leaf area & & & & & & & & & & & \\
\hline 3. Root fresh weight & & & & & & & & & & & \\
\hline 4. Root dry weight & & & & & & & & & & & \\
\hline 5. Root diameter & & & & & & & & & & & \\
\hline 6. Total yield & & & & & & & & & & & \\
\hline 7. Root crude protein & & & & & & & & & & & \\
\hline 8. Root Fe content & & & & & & & & & & & \\
\hline 9. Leaf chlorophyll & & & & & & & & & & & \\
\hline 10. Leaf carotenoid content & & & & & & & & & & & \\
\hline 11. Root carbohydrates & 1.00 & & & & & & & & & & \\
\hline 12. Root phenols content & $0.91^{+}$ & 1.00 & & & & & & & & & \\
\hline 13. Root tannins & $0.95^{+}$ & $0.85^{+}$ & 1.00 & & & & & & & & \\
\hline 14. Root flavonoids & $0.72^{+}$ & $0.75^{+}$ & $0.79^{+}$ & 1.00 & & & & & & & \\
\hline 15. Root anthocyanins & -0.09 & 0.11 & -0.05 & 0.14 & 1.00 & & & & & & \\
\hline 16. Leaf Fe content & 0.59 & 0.54 & $0.60^{+}$ & $0.84^{+}$ & 0.03 & 1.00 & & & & & \\
\hline 17. Leaf $\mathrm{Zn}$ content & $0.60^{+}$ & 0.53 & 0.58 & $0.76^{+}$ & -0.01 & $0.85^{+}$ & 1.00 & & & & \\
\hline 18. Photosynthetic rate & $0.67^{+}$ & $0.78^{+}$ & $0.69^{+}$ & $0.89^{+}$ & 0.32 & $0.87^{+}$ & $0.84^{+}$ & 1.00 & & & \\
\hline 19. Transpiration rate & -0.53 & -0.51 & -0.52 & $-0.75^{+}$ & 0.20 & $-0.94^{+}$ & $-0.94^{+}$ & $-0.79^{+}$ & 1.00 & & \\
\hline 20. Water use efficiency & $0.65^{+}$ & $0.74^{+}$ & $0.67^{+}$ & $0.90^{+}$ & 0.31 & $0.90^{+}$ & $0.87^{+}$ & $0.99^{+}$ & $-0.8+2$ & 1.00 & \\
\hline 21. Root $\mathrm{Zn}$ content & $0.75^{+}$ & $0.62^{+}$ & $0.73^{+}$ & $0.86^{+}$ & -0.09 & $0.91^{+}$ & $0.88^{+}$ & $0.75^{+}$ & $-0.8+2$ & $0.77^{+}$ & 1.00 \\
\hline
\end{tabular}

${ }^{+}$Significant at $p \leq 0.05$ 
and leaves. Additionally, a positive associations was observed between plant growth parameters (plant height, leaf area, and root diameter, fresh and dry biomasses of root) and total yield with leaf photosynthesis rate, $\mathrm{Zn}$ and $\mathrm{Fe}$ in roots and leaves. Similar association were observed for root carbohydrates content. High positive correlation was found between root carbohydrate with phenols and flavonoids. Similar positive correlation was found between phenols, flavonoids and $\mathrm{Zn}$ accumulation in leaves and roots. While above-mentioned parameters were significantly correlated negatively with leaf transpiration rate $(P \leq 0.05)$.

\section{Health risk assessment}

The data presented in Table 6 shows that the level of $\mathrm{Zn}$ and $\mathrm{Fe}$ in radish plants (roots and leaves) foliarly treated with $\mathrm{ZnO}$ and $\mathrm{FeO}$ GNPs. Calculated hazard quotient (HQ) was significantly higher for $\mathrm{Zn}$ and Fe in plants treated with T3 followed by T2 when compared to T1. Similar findings were recorded in HRI values. Minimum values of HRI were found in $\mathrm{T} 1$ while the maximum values were seen in T3 and T2. Despite, the values of HRI for $\mathrm{Zn}$ and $\mathrm{Fe}$ were lower the permissible limits set by to WHO/FAO (less than 1). No significant differences were found between treatments in DIM values.

\section{DISCUSSION}

The agribusiness sectors and consumers are more concerning to valuable food for basic nutrition and for health benefits. However, it is estimated that over sixty percent of world are iron deficient and over thirty percent are zinc deficient (Stein 2010). This situation is practically related to production of crops in regions with low mineral availability and / or consumption of food (Graham et al. 1992). In this connection, application of elements in nano forms, as fertiliser to reduce the adverse effects resulting of their deficiency edible parts of plants, is considered as a sustainable approach to correct their ratio in plants as well as improving nutritional quality. Generally, performance of nanoparticles is based on several properties such as size of particles, chemical structure, surface covering, rate and doses of application (Khodakovskaya et al. 2012). Zinc and $\mathrm{Fe}$ are essential elements for crop growth and production (Fageria 2016). Both microelements also are necessary in activation of many enzymes that existent in photosynthetic tissues and necessary for chlorophyll formation (Ramani \& Kannan 1985). It was reported that zinc play a vital role in activation of enzymes related to protein biosynthesis and metabolism of carbohydrates (Mathpal et al. 2015). In the current study, our results showed foliar application of $\mathrm{ZnO}$

$\mathrm{T}$ a

Calculation the health risk assessment for $\mathrm{Zn}$ and $\mathrm{Fe}$ in red radish roots supplied with chicken manure and $\mathrm{ZnO}+\mathrm{FeO} \mathrm{GNPs}$

\begin{tabular}{|c|c|c|c|c|c|c|}
\hline \multirow{2}{*}{\begin{tabular}{|l} 
Treatment \\
Microelement
\end{tabular}} & \multicolumn{2}{|c|}{$\begin{array}{l}\text { Chicken manure } \\
\text { (T1) }\end{array}$} & \multicolumn{2}{|c|}{$\begin{array}{c}\mathrm{FeO}+\mathrm{ZnO} \text { GNPs } \\
(\mathrm{T} 2)\end{array}$} & \multicolumn{2}{|c|}{$\begin{array}{c}\text { Chicken manure }+\mathrm{FeO}+\mathrm{ZnO} \text { GNPs } \\
(\mathrm{T} 3)\end{array}$} \\
\hline & $\mathrm{Fe}$ & $\mathrm{Zn}$ & $\mathrm{Fe}$ & $\mathrm{Zn}$ & $\mathrm{Fe}$ & $\mathrm{Zn}$ \\
\hline${ }^{(a)} \mathrm{R}_{f} \mathrm{D}$ & 0.3 & 0.7 & 0.3 & 0.7 & 0.3 & 0.7 \\
\hline (b) $\mathrm{B}$ & 65 & 65 & 65 & 65 & 65 & 65 \\
\hline${ }^{(c)} \mathrm{C}_{\text {factor }}$ & 0.085 & 0.085 & 0.085 & 0.085 & 0.085 & 0.085 \\
\hline HQ & $0.170 \pm 0.0^{\mathrm{c}}$ & $0.499 \pm 0.06^{\mathrm{c}}$ & $0.240 \pm 0.007^{\mathrm{b}}$ & $0.680 \pm 0.007^{\mathrm{b}}$ & $0.341 \pm 0.007^{\mathrm{a}}$ & $0.984 \pm 0.003^{\mathrm{a}}$ \\
\hline DIM & $0.01 \pm 0.0005^{\mathrm{a}}$ & $0.02 \pm 0.0009^{\mathrm{a}}$ & $0.02 \pm 0.0001^{\mathrm{a}}$ & $0.02 \pm 0.0008^{\mathrm{a}}$ & $0.02 \pm 0.007^{\mathrm{a}}$ & $0.03 \pm 0.0009^{\mathrm{a}}$ \\
\hline HRI & $0.039 \pm 0.0001^{\mathrm{b}}$ & $0.02 \pm 0.0013^{\mathrm{b}}$ & $0.06 \pm 0.0013^{\mathrm{a}}$ & $0.035 \pm 0.0021^{\mathrm{ab}}$ & $0.07 \pm 0.0009^{a}$ & $0.04 \pm 0.0017^{\mathrm{a}}$ \\
\hline
\end{tabular}

Values \pm SD followed by the same letter are not statistically different according to Tukey test $(P<0.05 \%)$. (a) RD (Food reference doses, $\mathrm{mg} / \mathrm{kg} /$ day) for $\mathrm{Zn}$ and $\mathrm{Fe}$ according to Yang and Liu (2012); (b) B = the average body weight was taken as $70 \mathrm{~kg}$ for adults according to WHO (1993); ${ }^{(\mathrm{c})}$ Conversion factor $\left(\mathrm{C}_{\text {factor }}=0.085\right)$ according to Latif et al. (2018). 
and FeO GNPs plus chicken manure caused a significant improvement in growth parameters (Table 3 ), as Chaudhuri \& Malodia (2017) reported. Additionally, the correlation study in Table 5 shows a positive correlation between agronomic traits as plant height, leaf area and root diameter and dry weight) with $\mathrm{Zn}$ and $\mathrm{Fe}$ content. Likewise, photosynthesis rate positively correlated to plant height $(r=0.73)$, leaf area $(r=0.78)$, chlorophyll content $(r=0.88)$, leaf carotenoids $(r=0.81)$, carbohydrates contents $(r=0.67)$, root diameters $(r=0.97)$ and total yield $(r=0.75)$. This indicates that growth and yield promotion of radish plant supplied with $\mathrm{ZnO}$ and $\mathrm{FeO}$ GNPs is associated highly to leaf photosynthetic pigments and photosynthesis rates that increase total carbohydrate accumulation which act as main component of dry matter. Such results confirmed by pervious reports in different vegetable crops (Prasad et al. 2012; Elizabath et al. 2017). Several researchers confirmed that the $\mathrm{Fe}$ and $\mathrm{Zn}$ either in normal forms or in nanoforms had improved leaf photosynthetic pigments and photosynthesis parameters (Duhan et al. 2017; Rattan et al. 2005). This could be attributed to interference of $\mathrm{Zn}$ and $\mathrm{Fe}$ in structural and catalytic component of proteins and enzymes for normal development of pigment biosynthesis and activation of photosynthesis (Rout \& Sahoo 2015; Mohammadi et al. 2018). Likewise, combined application of $\mathrm{ZnO}$ and $\mathrm{FeO}$ GNPs improved the nutritional value of red radish roots (Table 4). Interestingly, this application also significantly increased crude protein and total carbohydrate of radish roots. Moreover, higher concentration of secondary metabolic compounds (total phenols, tannins, flavonoids and anthocyanins) with foliar application of $\mathrm{ZnO}$ and $\mathrm{FeO}$ GNPs in this study was recorded (Table 4). This findings could be attributed to enhancement of carbohydrate. Where, carbohydrates are fundamental compounds essential to produce phenolic compounds through the shikimic acid pathway where extra carbohydrates derived from glycolysis and the pentose phosphate pathway are transformed into aromatic amino acids (Shui et al. 2009). Shui et al. (2009) reported that a higher concentration of secondary metabolites was associated to the equilibrium between carbohydrate source and sink; the increasing source-sink ratio, the higher production of secondary metabolites could be take placed.
Correlation study revealed that carbohydrates concentration positively correlated with total phenols $(r=0.91)$, tannins $(r=0.95)$, and flavonoids $(r=0.72)$, as shown in Table 5. Other scientist suggested that the accumulation of secondary metabolites is linked to enhancement of photosynthesis activity. A positive relationship was found between photosynthesis rates and total phenols $(r=0.78)$, tannins $(r=0.69)$ and flavonoids $(r=0.89)$. Both microelements ( $\mathrm{Zn}$ and $\mathrm{Fe}$ ) play a vital role in motivating photosynthesis processes and improving the translocation of carbohydrate to different parts of radish plant (Ghasemzadeh et al. 2011). The improvement of translocation indirectly could be increased the biosynthesis of total phenols, flavonoids, and tannins of treated plants with $\mathrm{ZnO}$ and FeO GNPs fertilisers (Kamenickova et al. 2013). Maximum $\mathrm{Zn}$ and $\mathrm{Fe}$ accumulations in different parts of radish plants were found in plants treated with combined treatment (Figure 3). Besides, a positive relationship between leaf $\mathrm{Zn}$ and Fe concentrations and root $\mathrm{Zn}$ and $\mathrm{Fe}$ contents $(r=0.88$ and $r=0.84$, respectively) was found, as shown in Table 5. In fact, concentration of $\mathrm{Zn}$ and $\mathrm{Fe}$ in roots supplied with $\mathrm{ZnO}$ and $\mathrm{FeO}$ GNPs did not reach to toxicity level according to data of health risk index (Table 6). Where, health risk index for $\mathrm{Zn}$ and $\mathrm{Fe}$ in roots did not across the allowable limit set by WHO/FAO (less than 1). This indicated that all treated plants with $\mathrm{ZnO}$ and $\mathrm{FeO}$ GNPs were fit for consumption.

\section{CONCLUSIONS}

Bio-nanotechnology is a recent area having many prospective to surely effect on the agriculture and food quality. Current investigation was concluded that combined application of $\mathrm{ZnO}$ and $\mathrm{FeO}$ GNPs (at rate $60 \mathrm{ppm}$ and $50 \mathrm{ppm}$, respectively) improved morphological and physiological traits as well as nutritional quality of red radish. Furthermore, upgraded of iron and zinc levels in radish roots did not leave any adverse impacts on human health. This study has identified that green synthesized nanofertilisers ( $\mathrm{ZnO}$ and $\mathrm{FeO})$ have simulative effects on the plant growth, quantity and quality of radish. 
Acknowledgements. The authors are thankful to the faculty of Agriculture, Cairo University for financing this research work.

\section{REFERENCES}

ABDEL-DAYEM, E.A. - ERRIQUENS, F. - VERRASTRO, V. - SASANELLI, N. - MONDELLI, D. - COCOZZA, C. 2012. Nematicidal and fertilizing effects of chicken manure, fresh and composted olive mill wastes on organic melon. In Helminthologia, vol. 49, no. 4, pp. 259-269. DOI 10.2478/ s11687-012-0048-4

ALLEN, S.F. - GRIMSHAW, H.F. - ROWL, A.B. 1984. Chemical Analysis. In MOOR, P.D. - CHAPMAN, S.B. (Eds.) Methods in plant ecology. Blackwell, Oxford, pp. 185-344.

ALLOWAY, B.J. 1995. Heavy Metals in Soils. London : Blackie Academic and Professional, Chapman and Hall, 368 p. https://doi.org/10.1007/978-94-011-1344-1

AOAC, 1990. Official methods of analysis of the Association of Official Analytical Chemists. 15th edition. Washington, DC, Association of Official Analytical Chemists.

BAĞ, H. - LALE, M. - TÜRKER, A.R. 1998. Determination of iron and nickel by flame atomic absorption spectrophotometry after preconcentration on immobilized sepiolite Saccharomyces Cerevisiae In Talanta, vol. 47, no. 3, pp. 689-696. DOI: 10.1016/S0039-9140(98)00104-0

BEVIS, L.E.M. 2015. Soil-to-human mineral transmission with an emphasis on zinc, selenium, and iodine. In Springer Science Reviews, vol. 3, no. 1, pp. 77-96. DOI: 10.1007/ s40362-014-0026-y

CATEL-FERREIRA, M. - TNANI, H. - HELLIO, C. - COSETTE, P. - LEBRUN, L. 2015. Antiviral effects of polyphenols: Development of bio-based cleaning wipes and filters. In Journal of Virological Methods, vol. 212, no.1, pp. 1-7. DOI:10.1016/j.jviromet.2014.10.008

CHAHARDEHI, A.M. - IBRAHIM, D.S. - SULAIMAN, F. 2009. Antioxidant activity and total phenolic content of some medicinal plants in Urticaceae family. In Journal of Applied Biological Sciences, vol. 3, no. 3, pp. 27-31.

CHAUDHURI, S.K. - MALODIA, L. 2017. Biosynthesis of zinc oxide nanoparticles using leaf extract of Calotropis gigantea: characterization and its evaluation on tree seedling growth in nursery stage. In Applied Nanoscience, vol. 7, no. 8, pp. 501-512. DOI 10.1007/s13204-017-0586-7

CUSHNIE, T.T. - LAMB, A.J. 2011. Recent advances in understanding the antibacterial properties of flavonoids. In International Journal of Antimicrobial Agents, vol. 38, no. 2, pp. 99-107. DOI.org/10.1016/j.ijantimicag.2011.02.014

DHIR, B. - SHARMILA, P. - PARDHA, S.P. - SHARMA, S. - KUMAR, R. - MEHTA, D. 2011. Heavy metal induced physiological alterations in Salvinia natans. In Ecotoxicology and environmental safety, vol. 74, no. 6, pp. 1678-1684. DOI:10.1016/j.ecoenv.2011.05.009

DUARTEA, L.J. - CHAVES, V.C. - DOS SANTOS NASCIMENTO, M.V.P. - CALVETE, E. - LI, M. - CIRAOLO, E. - GHIGO, A.- HIRSCH, E. - SIMÕES, C.M.O. - REGINATTO, F.H. - DALMARCO, E.M. 2018. Molecular mechanism of action of Pelargonidin-3-O-glucoside, the main anthocyanin responsible for the anti-inflammatory effect of strawberry fruits. In Food Chemistry, vol. 247, no. 1, pp. 56-65. DOI: 10.1016/j.foodchem.2017.12.015

DUHAN, J.S. - KUMAR, R. - KUMAR, N. - KAUR, P- NEHRA, K. - DUHAN, S. 2017. Nanotechnology: The new perspective in precision agriculture. In Biotechnology Reports, vol. 15, no. 2, pp. 11-23. DOI:10.1016/j.btre.2017.03.002 EC, 2007. Regolamento (CE) n. 834/2007 del Consiglio, del 28 giugno 2007, relativo alla produzione biologica e all'etichettatura dei prodotti biologici e che abroga il regolamento (CEE) n. 2092/91. https://eur-lex.europa.eu/legal-content/ IT/TXT/?uri $=$ celex\%3A32007R0834

ELANCHEZHIAN, R. - KUMAR, D. - RAMESH, K. BISWAS, A. - GUHEY, A. - PATRA, A.K. 2017. Morpho-physiological and biochemical response of maize (Zea mays L.) plants fertilized with nano-iron $\left(\mathrm{Fe}_{3} \mathrm{O}_{4}\right)$ micronutrient. In Journal of Plant Nutrition, vol. 40, no. 14, pp. 1969-1977. DOI:10.1080/01904167.2016.1270320

ELIZABATH, A. - BAHADUR, V. - MISRA, P. - PRASAD, V.M. - THOMAS, T. 2017. Effect of different concentrations of iron oxide and zinc oxide nanoparticles on growth and yield of carrot (Daucus carota L.). In Journal of Pharmacognosy and Phytochemistry, vol. 6, no. 4, pp. 1266-1269. http://www.phytojournal.com/archives/?year $=2017 \&$ vol $=6 \&$ issue $=4 \&$ ArticleId $=1497 \&$ si $=$ false

ERICE, G. - LOUAHLIA, S. - IRIGOYEN, J.J. - SÁNCHEZ-DÍAZ, M. - ALAMI, I.T. - AVICE, J.C. 2011. Water use efficiency, transpiration and net $\mathrm{CO}_{2}$ exchange of four alfalfa genotypes submitted to progressive drought and subsequent recovery. In Environmental and Experimental Botany, vol. 72, no. 2, pp. 123-130. DOI: 10.1016/j.envexpbot.2011.02.013

FAGERIA, N.K. 2016. The use of nutrients in crop plants. Boca Raton: CRC press, pp. 448. eBook ISBN 9781420075113 DOI: $10.1201 / 9781420075113$

FRANCIS, J.F. 1982. Analysis of anthocyanins. In MARKAKIS, P. (Ed.) Anthocyanins as good colors. London : Academic press, pp. 181-208.

GHASEMZADEH, A. - JAAFAR, H.Z.E. 2011. Effect of $\mathrm{CO}_{2}$ enrichment on synthesis of some primary and secondary metabolites in ginger (Zingiber officinale Roscoe). In International Journal of Molecular Sciences, vol. 12, no. 2, pp. 1101-1114. DOI: 10.3390/ijms12021101

GRAHAM, R.D. - ASCHER, J.S. - HYNES, S.C. 1992. Selecting zinc-efficient cereal genotypes for soils of low zinc status. In Plant and Soil, vol. 146, no. 1-2, pp. 241-250. https://link.springer.com/article/10.1007\%2FBF00012018

HELRICH, K. 1990. Official methods of analysis of the Association of Official Analytical Chemists. 15th ed., Arlington, USA : Association of Official Agricultural Chemist, $673 \mathrm{p}$.

HODSON, M.E. 2004. Heavy metals - geochemical bogey men? In Environmental Pollution, vol. 129, no. 3, pp. 341-343. DOI:10.1016/j.envpol.2003.11.003

IAVICOLI, I. - VERUSCKA, L. - BEEZHOLD, D.H. SHVEDOVA, A.A. 2017. Nanotechnology in agriculture: Opportunities, toxicological implications, and occupational risks. In Toxicology and Applied Pharmacology, vol. 329, pp. 96-111. DOI:10.1016/j.taap.2017.05.025

IBRAHIM, M.H. - JAAFAR, H.Z. - KARIMI, E. - GHASEMZADEH, A. 2012. Primary, secondary metabolites, photosynthetic capacity and antioxidant activity of the malaysian herb kacip fatimah (Labisia pumila benth) exposed to potassium fertilization under greenhouse conditions. In International Journal of Molecular Sciences, vol. 13, no. 11, pp. 15321-15342. DOI: 10.3390/ ijms 131115321

KHAN, M.U. - MALIK R.N. - MUHAMMAD, S. - ULLAH, F. - QADIR, A. 2015. Health risk assessment of consumption of heavy metals in market food crops from Sialkot and Gujranwala Districts, Pakistan. In Human and Ecological Risk Assessment: International Journal, vol. 12, no. 2, pp. 327-337. DOI: 10.1080/10807039.2014.913445 
KHODAKOVSKAYA, M.V. - DE SILVA, K. - BIRIS, A.S. - DERVISHI, E. - VILLAGARCIA, H. 2012. Carbon nanotubes induce growth enhancement of tobacco cells. In ACS Nano, vol. 6, no. 3, pp. 2128-2135. DOI: $10.1021 / \mathrm{nn} 204643 \mathrm{~g}$

KITAMURA, S. 1958. Cultivars of radish and their change. In NISHIYAMA, I. (Ed.) Japanese Radish. Tokyo : Japan Society for the Promotion of Science, pp. 1-19.

LATIF, A. - BILAL, M. - ASGHAR, W. - AZEEM, M. AHMAD, M.I. - ABBAS, A. - AHMAD, M.Z SHAHZAD, T. 2018. Heavy metal accumulation in vegetables and assessment of their potential health risk. In Journal of Environmental Analytical Chemistry, vol. 5, no. 234, pp. 2380-2391. DOI:10.4172/23802391.1000234

MATHPAL, B. - SRIVASTAVA, P.C. - SHANKHDHAR, D. - SHANKHDHAR, S.C. 2015. Improving key enzyme activities and quality of rice under various methods of zinc application. In Physiology and Molecular Biology of Plants, vol. 21, no. 4, pp. 567-572. DOI: $10.1007 /$ s12298-015-0321-3

MEDA, A. - LAMIEN, C.E. - ROMITO, M. - MILLOGO, J. - NACOULMA, O.G. 2005. Determination of the total phenolic, flavonoid and praline contents in Burkina Fasan honey, as well as their radical scavenging activity. In Food Chemistry, vol. 91, no. 3, pp. 571-577. DOI: 10.1016/j.foodchem.2004.10.006

MISHRA, S. - KESWANI, C. - SINGH, A. - SINGH, B.R. - SINGH, S.P. - SINGH, H.B. 2016. Microbial nanoformulation: Exploring potential for coherent nanofarming. In The Handbook of Microbial Resources, pp.107-120. https://www.cabi.org/animalscience/ebook/20163199950

MOHAMMADI, M. - HOSEINI, N.M. - CHAICHI, M.R. - ALIPOUR, H. - DASHTAKI, M. - SAFIKHANI, S 2018. Influence of nano-iron oxide and zinc sulfate on physiological characteristics of peppermint. In Communications in Soil Science and Plant Analysis, vol. 49, no. 18 pp. 2315-2326. DOI: 10.1080/00103624.2018.1499766

MÜLLER-MAATSCH, J. - BECHTOLD, L. - SCHWEIGGERTA, R.M. - CARLEAB, R. 2016. Co-pigmentation of pelargonidin derivatives in strawberry and red radish model solutions by the addition of phenolic fractions from mango peels. In Food Chemistry, vol. 213, no. 3, pp. 625-634. DOI:10.1016/j.foodchem.2016.06.097

MRVCIC, P.T. - BARISIC, L. - STANZER, D. - BACUN-DRUZINA, V. - STEHLIK-TOMAS, V. 2009. Zinc binding by lactic acid bacteria. In Food Technology \& Biotechnology, vol. 47, no. 4, pp. 381-388. https://hrcak. srce.hr/43896?lang=en

NADERI, M.R. - ABEDI, A. 2012. Application of nanotechnology in agriculture and refinement of environment pollutants. In Journal of Nanotechnology, vol. 11, no. 1, pp. $18-26$

NORNAI, R. 1982. Formulae for determination of chlorophyllous pigments extracted withN,N-dimethylformamide. In Plant Physiology, vol. 69, no. 6, pp.1376-1381. DOI: $10.1104 /$ pp.69.6.1376

PRASAD, M.N.V. 2004. Heavy metal stress in plants. From biomolecules to ecosystems. Berlin, Heidelberg : Springer-Verlag, 2nd Ed., 462 p. DOI: 10.1007/978-3-66207743-6

PRASAD, R. - KUMAR, V. - PRASAD, K.S. 2014. Nanotechnology in sustainable agriculture: present concerns and future aspects. In African Journal of Biotechnology, vol. 13, no. 6, pp. 705-713. DOI:10.5897/ AJBX2013.13554
PRASAD, T.N.V.K.V. - SUDHAKAR, P. - SREENIVASULU, Y. - LATHA, P. - MUNASWAMY, V. - REDDY, K. - SREEPRASAD, T.S. - SAJANLAL, P.R. - PRADEEP, T. 2012. Effect of nanoscale zinc oxide particles on the germination, growth and yield of peanut. In Journal of Plant Nutrition, vol. 35, no. 6, pp. 905-927. DOI:10.108 0/01904167.2012.663443

RAMANI, S. - KANNAN, S. 1985. Studies on Zn uptake and influence of $\mathrm{Zn}$ and $\mathrm{Fe}$ on chlorophyll development in young maize cultivars. In Journal of Plant Nutrition, vol. 8, no. 12, pp. 1183-1189. DOI: 10.1080/01904168509363416

RASHID, A. - RYAN, J. 2004. Micronutrient constraints to crop production in soils with Mediterranean-type characteristics: A Review. In Journal of Plant Nutrition, vol. 27, no. 6, pp. 959-975. DOI: 10.1081/PLN-120037530

RATTAN, R.K. - DATTA, S.P. - CHHONKAR, P.K. - SURIBABU, K. - SINGH, A.K. 2005. Long-term impact of irrigation with sewage effluents on heavy metals content in soils, crops and ground water. In Agriculture, Ecosystems \& Environment, vol. 109, no. 3-4, pp. 310-322. DOI:10.1016/j.agee.2005.02.025

ROUT, G.R. - SAHOO, S. 2015. Role of iron in plant growth and metabolism. In Reviews in Agricultural Science, vol. 3, pp.1-24. DOI: 10.7831/ras.3.1

RUBINSKIENE, M. - JASUTIENE, I. - VENSKUTONIS, P.R. - VISKELIS, P. 2005. HPLC determination of the composition and stability of blackcurrant anthocyanins. In Journal of Chromatographic Science, vol. 43, no. 9, pp. 478-82. DOI:10.1093/chromsci/43.9.478

SEKHON, B.S. 2014. Nanotechnology in agri-food production: an overview. In Nanotechnology, Science and Applications, vol. 7 , no. 1 , pp. 31-53. DOI: 10.2147/NSA. S39406

SHUI, Y.C. - FENG, X. - YAN, W. 2009. Advances in the study of flavonoids in Gingko biloba leaves. In Journal of Medicinal Plants Research, vol. 3, no.13, pp. 1248-1252. DOI: $10.5897 / \mathrm{JMPR}$

SINGLETON, V.L. - ROSSI, J.A. 1965. Colorimetry of total phenolics with phosphomolybdic phosphotungstic acid reagents. In American journal of Enology and Viticulture, vol. 16, no. 3, pp. 144-158. http://www.ajevonline. org/content/16/3/144.full.pdf + html.

STEIN, A.J. 2010. Global impacts of human mineral malnutrition. In Plant and Soil, vol. 335, no.1-2, pp. 133-154. DOI: 10.1007/s11104-009-0228-2

TROY, S.M. - NOLAN, T. - KWAPINSKI, W. - LEAHY, J.J. - HEALY, M.G. - LAWLOR, P. 2012. Effect of sawdust addition on composting of separated raw and anaerobically digested pig manure. In Journal of Environmental Management, vol. 111 , no. 2 pp. 70-77. DOI: org/10.1016/j.jenvman.2012.06.035

THAKUR, S. - THAKUR, S. - KUMAR, R. 2018. Bio-nanotechnology and its role in agriculture and food industry. In Journal of Molecular and Genetic Medicine, vol. 12 , no. 324 , pp. 1747-0862. DOI: $10.4172 / 1747-$ 0862.1000324

TROY, S.M. - NOLAN, T. - KWAPINSKI, W. - LEAHY, J.J. - HEALY, M.G. - LAWLOR, P. 2012. Effect of sawdust addition on composting of separated raw and anaerobically digested pig manure. In Journal of Environmental Management, vol. 111 , no. 2 pp. $70-77$. DOI: org $/ 10.1016 /$ j.jenvman.2012.06.035

USDA. 1998. Keys to soil taxonomy. United States Department of Agriculture, New York.

WANG, X. - SATO, T. - XING, B. - TAO, S. 2005. Health rick of heavy metals to the general public in Tianjin, Chi- 
na via consumption of vegetables and fish. In Science of the Total Environment, vol. 350, no. 1-3, pp. 28-37. DOI:10.1016/j.scitotenv.2004.09.044

WELCH, R.M. - SHUMAN, L. 1995. Micronutrient nutrition of plants. In Critical Reviews in Plant Sciences, vol. 14, no.1, pp. 49-82. DOI: 10.1080/07352689509701922

WORLD HEALTH ORGANIZATION [WHO], 1993. Evaluation of certain food additives and contaminants. In Forty- First Report of the joint FAO/ WHO Expert Com- mittee on Food Additives, WHO. Geneva, Switzerland (WHO Technical Series, 837).

YANG, T. - LIU, J. 2012. Health risk assessment and spatial distribution characteristic on heavy metals pollution of Haihe River Basin. In Journal of Environmental \& Analytical Toxicology, vol. 2, no. 6, pp. 1-5. DOI: 10.4172/2161-0525.1000152

Received: February 4, 2019 Accepted: April 2, 2019 